\title{
Redacted Text, 2019: Statement from the Artist
}

The image on the cover is taken from Chantal Gibson's Redacted Text, 2019 and is part of Gibson's Historical In(ter)ventions series, a collection of altered texts she began creating in 2010 that range from small handheld books to large-scale installations.

\section{Statement from the Artist}

I am a/Historical In(ter)ventionist in the process of decolonizing my body and mind. Using black braided thread and sticky liquid rubber, my altered book sculptures (2010-21) challenge how we create knowledge and construct nationhood. Presented as methods of communication, rather than containers of fixed truth, these dismantled structures question what is included and what is not. They scratch at ideology, undoing tropes and myths, provoking viewers to consider other ways of knowing: What does it mean to read texture over text? How do we mark the voices, the stories, and the bodies that have been violently, systemically erased, silenced, or excluded from dominant Canadian cultural narratives?

Chantal Gibson is an artist-educator living on the unceded ancestral lands of the Coast Salish Peoples. Working in the overlap between literary and visual art, she confronts colonialism head on, imagining BIPOC voices silenced in the spaces left by systemic cultural and institutional erasure. Her work has been exhibited in galleries across Canada and the United States, most recently in the Senate of Canada. Gibson's debut book of poetry, How She Read (2019), uses text and image to address the mis/representation of Black women across the Canadian cultural landscape. It was the winner of the 2020 Pat Lowther Memorial Award and the Dorothy Livesay Poetry Prize and a finalist for the 2020 Griffin Poetry Prize. A 2021 3M National Teaching Fellow, Gibson facilitates decolonizing curriculum workshops in classrooms and institutions across the country. She teaches in the School of Interactive Arts and Technology at Simon Fraser University. 
This page intentionally left blank 